\title{
THE MANAGEMENT OF PRODUCTION/SERVICES UNIT IN BUSINESS AND MARKETING EXPERTISE PROGRAM IN STATE VOCATIONAL HIGH SCHOOL 2 SINGKAWANG
}

\author{
Gunanto \\ Educational Administration Master Program, Tanjungpura University \\ Pontianak, Indonesia \\ E-mail: gunantows@gmail.com
}

\begin{abstract}
A school's production/services unit (P/SU) constitutes a process of business activity for both academic and commercial purpose that the school performs continuously by empowering the school's members and environment in the form of professionally-managed production/ services business unit.

This research aims at 1) describing the planning of production/services unit in Business and Marketing Expertise Program at State Vocational High School 2 Singkawang, 2) describing the organization of production/services unit in Business and Marketing Expertise Program at State Vocational High School 2 Singkawang, 3) describing the operation of production/services unit in Business and Marketing Expertise Program at State Vocational High School 2 Singkawang, 4) describing the monitoring of production/services unit in Business and Marketing Expertise Program at State Vocational High School 2 Singkawang, 5) describing the obstacles encountered in managing the production/services unit in Business and Marketing Expertise Program at State Vocational High School 2 Singkawang, 6) describing the efforts made to deal with these obstacles encountered in managing the production/services unit in Business and Marketing Expertise Program at State Vocational High School 2 Singkawang.

The approach in this research is qualitative strengthened with descriptive method. The research focus is on the management of production/services unit in Business and Marketing Expertise Program at State Vocational High School 2 Singkawang in such aspects as planning, operation, organization and monitoring. The data are gathered using interview, observation and documentation.

The research findings are: 1) The planning of production/services unit in Business and Marketing Expertise Program at State Vocational High School 2 Singkawang takes the school's vision and missions and its education and business aspects into consideration, 2) the organization begins with the establishment of administrators and drafting the main job descriptions and functions of each department in a clear and comprehensible language, 3) The field executors actively involved in the production unit's activities as daily sales service officers are those selected students from the so-called Alfamart class which constitutes a cooperation between the school and PT. Sumber Alfaria Trijaya Tbk., 4) the presence of this Business and Marketing Expertise Program's production unit has been capable of adding more places and increasing the capacity for apprentice or industrial work practice students, 5) the monitoring of production unit is performed towards officer's behavior, customers,
\end{abstract}


administration and good stock. Finally, 6) the more spacious room needs to be immediately selected based on the capacity and service duration in order to optimize the potential customers which amount to more than 1,200 students and teachers.

Keywords: Management, Production/Services Unit, Business, Marketing

\section{Introduction}

A school's production/services unit (P/SU) constitutes a process of business activity for both academic and commercial purpose that the school performs continuously by empowering the school's members and environment in the form of professionally-managed production/ services business unit. Bambang Sartono in Materi Pembinaan Kompetensi Calon Kepala Sekolah/Kepala Sekolah [Materials for Future Principal/Principal's Competence Development] (Depdiknas, 2007:6) also states that an SMK/MAK's (Sekolah Menengah Kejuruan [Public Vocational Senior High School]/Madrasah Aliyah Kejuruan [Islamic Vocational Senior High School]) production/services unit is a place of entrepreneurship in schools, thus it should be managed for both academic and commercial purpose and institutionalized in a business organization. The presence of production/services unit at Vocational Senior High School is highly important and one can even say that its existence is compulsory.

SMK is an educational institution directed towards the creation of skilled and professional labors profesional to allow their placement in both business and industry world. Also, it tries to keep their graduates' skills up to date by developing their entrepreneurship mentality. This is in accordance with the Government Regulation Number 29 year 1990 which formulates that "Vocational Secondary Education shall prioritze the preparation of students to work and to develop their professional attitude". State Vocational High School 2 Singkawang is a State Vocational High School in Singkawang Municipality and it has expertise programs it has developed, they are Accounting Expertise program which aims at producing accounting and bookkeeping professionals, Office Administration Expertise program which has the purpose of generating competent graduates in the field of organizing office administration, Business and Marketing Expertise Program with its goal of producing graduates skilled business and marketing fields, Multimedia Expertise program which strives to generate manpower adept at communication technology and its supporting devices and finally Pharmacy/Health Expertise program with its objective to produce competent graduates in pharmacy/health service field. This school also has many advantages, including: (1) Trusted by the Ministry of Education and Culture as the only Referred Vocational High School in Singkawang Municipality, (2) Having been certified with ISO 9001;2008 from a well-known Certification Institution since 2012 until recently, (3) Constantly superior in many Academic and Non-Academic achievements, and (4) Located highly strategically at the heart of the town leading to its great accessibility.

In order to produce competent, skilled labors in their respective fields, State Vocational High School 2 Singkawang have made various attempts in order for its graduate to either work for others or create their own businesses. One program to support this is performed through production unit activity at the school. In addition to strengthen the hard skills that the students have, they are involved in this production unit to obtain knowledge on how to manage certain types of business (soft skill). This effort is compliant with the Government Regulation Number 29 year 1990 in article 29 paragraph2, which states that: "in order to prepare SMK students to be workers, at SMKs a Production unit which operates professionally can be established". 
The production/services unit in State Vocational High School 2 Singkawang, especially the one in Business dan Management Expertise field in Business and Marketing Expertise Program can develop well and even bind cooperation with business/industry world (DU-DI) as inaugurated through Memorandum of Understanding (MOU) between State Vocational High School 2 Singkawang and Alfamart. Therefore, this production/services unit can actually benefit the school's members and surrounding society alike. Based on the preliminary observation that the researcher has conducted through some discussions with the principal as well as with vocational teachers, it is found that it has encountered some obstacles. These obstacles standing in the way of the development of production unit include (1) limited working capital to purchase tools and materials; (2) teacher's difficulty in managing their time to teach in classroom and to guide the production unit; (3) the fact that not all teachers have shared the same understanding on this production unit development program, hence some of these teachers object the idea of allowing their students to join the production unit practice activity during their lesson; (4) students' motivation in executing the practice learning in this production unit is still low, with some of them being unaware that this production unit constitutes a means of practice to improve their skills; (5) the difficulty encountered to build cooperation with business world to develop this production unit.

The researcher is interested in studying the management of this production/services unit in Business and Marketing Expertise Program at State Vocational High School 2 Singkawang. The reasons as to why this research makes it its object are: (1) Its business activities are done within SMKN 2 Singkawang. (2) its business location is easily accessible, (3) the responsibility for managing this Business and Marketing Expertise Program's production/services unit falls fully to the school, (4) The management of this production/services unit is mostly done by the school's members rather than the supporting industry, (5) There is profit that the school receives from this school's production/services unit activities to help the education financing, (6) the number of students and teachers as well as staff/employees which amount to more than 1200 can be used as potential future customers which can be the target market for its production unit activity (7) the cooperation with business world has lasted for more than a year, thus the management should be eligible to be a topic for research, and (8) the cooperation between this production/services unit in Business and Marketing Expertise Program at State Vocational High School 2 and the industry world has been lasting continuously.

\section{Literature Review}

Management is an activity performed to facilitate the achievement of common goals in an organization as well as to manage all of organization's resources, such as facilities and infrastructures, time, HR, methods and other in an effective, innovative, creative, solutive, and efficient manner. The researcher concludes that management is an activity held continuously where planning, organization, operation and monitoring in managing the existing resources serve as parts of a set of activities done in stages to achieve the goals.

Graduation standards are the main reference to develop content standards, process standards, educational evaluation standards, educator and education staff standards, facility and infrastructure standards, management standards, and financing standards. In the Ministerial Regulation of Education and Culture Number 20 year 2016, it is stated that "Graduate Competence Standards are the criteria regarding the qualification of graduates' ability which include attitude, knowledge, and skills". Thus, the Graduate Competence Standards consist of students ability qualification criteria which are expected to be achieved when they complete their study in the school at SMK education level. One of the efforts to 
pass this graduate competence standards is by developing school's production unit at each expertise program in the vocational senior high school. Vocational senior high school prioritizes the development of students' ability to perform certain kinds of job, therefore SMK administers education programs as adjusted to the types of occupation. In relation to this, SMK is classified into several expertise fields, which includes several expertise programs and deteiled further into several expertise competences.

The management of production/services unit at schools deals with business and education aspects, hence this production/services unit needs to be managed well and properly in order to achieve the goals. Whether the production unit in SMK fails or succeeds, it is highly dependent on the management applied in the relevant school. Therefore, it is important to strengthen the SMK management in order for the production unit to be developed in the effort of improving the graduate's competitiveness.

\section{Methodology}

This research uses qualitative approach. The qualitative data are analyzed during the research term, i.e. from the beginning to the end, without having to wait until all data are completely gathered. The data analysis begins with a review of a number of data which are available from many sources, i.e. interview, observation, and documentation. The presentation of data in this research is done by collecting the prepared information which gives the possibility of drawing conclusion and taking action. By observing the data on the management of production/services unit in Business and Marketing Expertise Program at SMKN 2 Singkawang, we will be able to grasp what is happening and what should be done further, either to analyze or to take action based on the obtained understanding and presentations.

The analysis performed on all of the data and information obtained through interview, observation and document collection regarding the management of production/services unit in Business and Marketing Expertise Program at State Vocational High School 2 Singkawang. The researcher analyzes the interview result based on her understanding on what are revealed by the respondents, the observation and documentation results during the data collection process. The classified data are then reviewed by the researcher thoroughly and important themes and their key words are found. This way, the research can capture the experience, problems, and dynamic occuring in the subject.

\section{Result and Discussion}

When it comes to the planning of production/services unit, thanks to this planning of production/services unit, all elements of parts can do their jobs in a directed and measurable manner for they have a clear guideline. The management of production unit should also be initiated with a good planning.

In regard to the organization of production/services unit, the structure of administrators of production unit has been adequate, yet some of these administrators assume double positions, particularly the chief of Business and Marketing Expertise Program who is also the chief of production/services unit while in the articles of association it is stated the expertise program chief shall assume the position of Supervisor. The solution offered for this problem is to amend the provisions of production/services unit's Articles of Association or to appoint a teacher who is not assuming any position in the school's organizational structure as the chief of production/services unit to allow a more optimal administrative function. 
In terms of the operation of production/services unit, the sales services activities performed by students have been implemented smoothly. The students appointed to perform the daily attendant duty can skillfully operate the sales system as implemented in the sales business retail. Even if it is just a half of the total number of students who want to shop in this production/services unit, then it is impossible to provide the best service from both time and capacity perspectives. The researcher offers a solution, which is if it is possible to establish a promotional duty officers who are tasked specifically to be representatives of their classmates who want to buy something from the unit, hence not all of them should come in huddle and queue too long to choose and pay the goods they buy.

As to the monitoring of production/services unit, it has been executed by the officers in charge of marketing and finance. However, the monitoring has not used the monitoring reference standards. In addition to serving the customers, those students in daily attendant duty also oversee or monitor, to be precise, the customers who are choosing which goods they want to buy in order to prevent any fraud. For this reason, the installation of CCTV as an aid of monitoring shall better be immediately realized. Until this aid of monitoring is installed, for this time being it can be dealt with by adding the number of students to be the attendants. This also serves as an opportunity provided to more students to have some time to practice in this production/services unit.

Speaking of the obstacles encountered and the efforts to solve them, as informed by the principals of SMKs in Singkawang Municipality, generally the obstacles they encounter in developing this production unit's activities are (1) limited working capital to purchase tools and materials; (2) teacher's difficulty in managing their time; (3) students' low motivation in executing the practice learning in this production unit; (4) the difficulty in building cooperation with the business world to develop the production unit (5) the limited time for operating the production unit's activities, and (6) minimum amount of finance.

The production unit in Business and Marketing Expertise Program at State Vocational High School 2 Singkawang has been proven successful in dealing with some of these obstacles. The capital, equipment and technical obstacles are overcome by cooperating with the business partner Alfamart and Allice es-cream. The limited time obstacle is dealt with by giving discounts and improving the promotional activities. Meanwhile, those obstacles which have something to do with teachers and students, the principal is actively involved in giving explanation and motivation during meetings, ceremonies and other opportunities in order for all parties to contribute to the successful development of this school's production unit.

It is also important to intensify the promotion and dissemination to the society around the school to help increase the sales of available products. It is urgent to procure a more spacious room for the production/services unit's activity by either utilizing the less productive rooms or submitting a proposal for room procurement to the government.

\section{Conclusion}

\section{Planning of Production/Services Unit}

The planning of production/services unit in Business and Marketing Expertise Program at SMKNegeri 2 Singkawang has been performed well, where the production/ services unit's formulated vision and missions and goals supports the achievement of school's vision and missions. The establishment of production unit is decided in teacher's board meeting and performed together with the business world, including the planning analysis in the form of analysis of strengths, weaknesses, opportunities and threats (SWOT analysis) in the process of planning of production unit establishment. 


\section{Organization of Production/Services Unit}

The organization in this production unit activity in Business and Marketing Expertise Program at State Vocational High School 2 Singkawang has been performed well, as indicated by the cooperation agreement with the business world which allow them to avoid overlapping authorities and the independence of those students in daily duty who can perform their jobs well and smoothly. The organizational structure needs to add Study Program Chief and secretary in order to realize what has been formulated in the Articles of Association. Additionally, there should be no overlapping authorities between the school and the business world as its business partner.

\section{Operation of Production/Services Unit}

The production unit in Business and Marketing Expertise Program at State Vocational High School 2 Singkawang has been operated well. The students actively involved in the production unit activities are selected from the so-called Alfamart class which is established and nurtured by the school and PT. Sumber Alfaria Trijaya Tbk. The service in this production unit is provided beyond the learning hours, thus it would not interfere with their learning time. The sales and finance are administered professionally as generally applicable to all Alfamart minimarts. The practice activity that students perform is directed towards the achievement of graduate's competence standards.

\section{Monitoring of Unit Production/Service}

The production/services unit in Business and Marketing Expertise Program at State Vocational High School 2 Singkawang is monitored in a simplified manner. They have not used measurable reference standards. The daily regular monitoring is done by the administrators in charge of finance and marketing. Meanwhile, the business world as a its supporting partner performs the monitoring periodically. The customer monitoring has yet used CCTV technology.

\section{The obstacles encountered and the efforts made to solve them}

The obstacles in the planning of this production/services unit in Business and Marketing Expertise Program at State Vocational High School 2 Singkawang have been dealt with well. In the organization though some still have double positions as study program chief and production unit chief. The obstacle in the operation of production unit which has not been dealt with is the recruitment of workers designated specifically for sales service other than from the school's students. Finally, the CCTV will be immediately installed to support the monitoring.

\section{References}

Chandrawasih, Chr. I. Gst. Ay. (2012). Implementasi pendidikan internship industry (magang) program Program keahlian tata boga melalui pengelolaan unit produksi (Studi Kasus pada SMK Kridawisata Bandar Lampung). Tesis. Magister Manajemen Universitas Bandar lampung.

Depdiknas. (1997). Pedoman Pelaksanaan Unit Produksi SMK. Jakarta.

Handoko, T. Hani. (2009). Manajemen. Yogyakarta: BPFE-Yogyakarta.

Hariri, Hasan., dkk. (2016). Manajemen Pendidikan. Yogjakarta: Media Akademi.

Ixtyarto, Bambang (2015). Pengelolaan Kemitraan SMK Dengan Dunia Usaha dan Dunia Industri (Studi Kasus pada SMK Muhammadiyah 2 Wuryantoro Kab. Wonogiri). Tesis. Program Pascasarjana Univ. Muhammadiyah Surakarta.

John M. Ivancevic. (2007). Human Resources Management. Singapore. McGraw-Hill/Irwin.

John W. Creswell. (2007). Qualitative Inquiry \& Research design Coosing Among Five Approachches. California University Of Nebraska, Sage Publications. 
Kemendikbud. (2013). Program Kegiatan Produksi dan Jasa Sekolah/Madrasah. Karanganyar: LPPKS Indonesia.

Mardiana. (2013). Kinerja kepala sekolah dalam mengembangkan unit produksi (Studi Deskriptif Kualitatif di SMKN I Bengkulu Selatan). Tesis. Magister Manajemen Pendidikan Universitas Bengkulu.

Martubi, Satunggalno. (2012). Model-Model Penyelenggaraan Unit Produksi di Sekolah Menengah Kejuruan Daerah Istimewa Yogyakarta. Laporan Penelitian IKIP Yogyakarta.

Maswardi. M. Amin dan Yuliananingsih. (2016). Manajemen Mutu, Aplikasi dalam Bidang Pendidikan. Media Akademi Yogyakarta.

Mergono. (2014). Metolodogi Penelitian Pendidikan. Jakarta: Rinekacipta, Cetakan IX.

Miles. M.M. \& Huberman. A.M. (1994). Qualitative Data Analysis. Second Edition. London: SAGE Publications Inc.

Moleong, Lexy, J. (2004). Metodologi Penelitian Kualitatif. Bandung: P.T. Remaja Rosdakarya.

Peraturan Menteri Diknas. No. 13 tahun 2007 tentang Kompetensi Kepala Sekolah. Jakarta: Depdiknas.

Peraturan Pemerintah Republik Indonesia Nomor 29 tahun 1990 tentang Pendidikan Menengah. Departemen Pendidikan dan Kebudayaan, Jakarta.

Permendikbud, RI. (2016). Standar Kompetensi Lulusan Pendidikan Dasar dan Menengah. Jakarta: Dirjend Kemkumham.

Priyono. (2007). Pengantar Manajemen. Surabaya: Zitama Publisher.

Ramasamy, T. (2014) Principal of Management. Mumbai: Himalaya Publishing House.

Raymond, J. Stone (2008). Human Resource Management. Australia: Wiley \& Son.

Republik Indonesia. (2003). Undang-undang No. 20 tahun 2003 tentang Sistem Pendidikan Nasional: Setneg.

Roskina, Mas, Sitti. (2013). Kompetensi kewirausahaan kepala sekolah dalam mengelola unit produksi hotel pendidikan (Studi Multi Kasus Pada SMKN 3 Malang, SMKN 2 Malang, dan SMKN 1 Buduran). Laporan akhir Disertasi Doktor. Universitas Negeri Gorontalo.

Roskina, Mas, Sitti. (2017). Kewirausahaan Kepala Sekolah. Yogyakarta: Zahir Publishing.

Rosset, Alison. (1989). Training Need assessment, New Jersey: Education Technology Pucications, Inc., Englewood Cliffs.

Rusnani dan Moerdiyanto. (2012). Pelaksanaan Unit Produksi pada SMK Negeri Kelompok Bisnis dan Manajemen di Banjarmasin. Abstrak Hasil Penelitian PPs-UNY. Yogyakarta: Lembaga Penelitian UNY.

Sallis, E. (1993). Total Quality Management In Education. London: kogan Page Ltd.

Singgih Darjanto. (2012). Manajemen Unit Produksi dan Jasa di Sekolah Menengah Kejuruan Umar Fatah Rembang. Jurnal of Economic Education. Universitas Negeri Semarang.

Siswanto, Ibnu. (2015). Faktor Pendukung dan Penghambat Pelaksanaan Unit Produksi di SMK Daerah Istimewa Yogyakarta. Jurnal PPKM II 77-83. Universitas Negeri Yogyakarta.

Stephen P. Robin and Mary Coulter. (2013). Management. London Person Education.

Sugiyono. 2010. Metode Penelitian Pendidikan, Pendekatan Kuantitatif, kualitatif dan RED. Bandung: Alfabeta.

Swityawastuti, Budi. (2014). Manajemen unit produksi berbasis produk di SMK Negeri 7 Purworejo. Tesis. Program Pascasarjana Universitas Muhammadiyah Surakarta.

Tony Bush and David Middlewood. (2008). Leading and Managing People in Education. California. Sage Publications Inc. 
Jurnal Terapan Manajemen dan Bisnis

Volume 4 Number 1 March 2018. Page 107-114

e-ISSN: 2477-5282 p-ISSN: 2599-3127

Tukiran, Martinus. (2016). Membangun Sistem Manajemen Mutu Berdasarkan ISO 9001:2015. Yogyakarta: LeutikaPrio.

Usman, Husaini. (2006). Manajemen: teori, praktik, dan riset pendidikan. Jakarta: Bumi Aksara

Zamzam Zawawi Firdaus. (2012). Pengaruh Unit Produksi, Prakerin dan Dukungan Keluarga terhadap Kesiapan Kerja Peserta didik SMK. Jurnal Pendidikan Vokasi, Vol 2, Nomor 3, November 2012. 